УДК $811.111: 81$ '373

DOI https://doi.org/10.26661/2414-1135-2021-83-12

\title{
СЛОВОСКЛАДАННЯ ТА СЛОВОЗЛИТТЯ ЯК СПОСОБИ УТВОРЕННЯ НЕОЛОГІЗМІВ ПАНДЕМІЇ СОVID-19 В АНГЛІЙСЬКІЙ МОВІ
}

\author{
Журкова О. Л. \\ кандидат філологічних наук, \\ дочент кафедри іноземної філології та перекладу \\ Київський національний торговельно-економічний університет \\ вул. Кіото, 19, Київ, Україна \\ orcid.org/0000-0001-8113-7196 \\ o.zhurkova@knute.edu.ua
}

Ключові слова: контаміначія, телескопія, слова-бленди, інновати, оказіоналізми.
У статті обгрунтовується доцільність вивчення неологізмів сучасної англійської мови, що репрезентують концептосферу «пандемія COVID-19». Актуальність дослідження пояснюється підвищеною увагою до впливу коронавірусу на лінгвістичні процеси, у тому числі появу загальномовних та оказіональних інноватів, які становлять не лише науковий інтерес, а й суспільно-соціальну вагу. У розвідці здійснюється спроба аналізу способів збагачення сучасної англійської мови коронавірусними мовними одиницями на прикладах неологізмів, відібраних 3 англомовних сайтів та Інтернет-видань британської та американської преси. Під неологізмами розуміються нові слова, що закріплюються в мові і створені актом номінації; можуть з'являтися для позначення нових понять або для позначення по-новому вже наявних понять. Дослідження практичного матеріалу доводить, що збільшення словникового складу англійської мови відбувається переважно через зміну значення наявних понять і шляхом словотворення. Крім того, виявлено, що серед неологізмів пандемії COVID-19 переважають такі, що утворені способами словоскладання (compounding) і словозлиття (blending), тоді як найбільш продуктивними компонентами для новоутворених слів-блендів $\epsilon$ coronavirus/corona, COVID, quarantine, lockdown. Останнім часом спостерігається тенденція до збільшення лексичних одиниць-блендів, а спосіб словозлиття/блендингу переходить з розряду другорядних у категорію основних. Пандемійні бленди (контамінанти) не тільки називають нові поняття й реалії в стислій формі, а й виконують емотивну функцію, унаслідок чого інновати часто отримують негативне конотативне значення через несхвальне емоційне ставлення до пандемії як такої. Зазначимо, що пропонована стаття не претендує на вичерпність, оскільки пандемія COVID-19 і досі триває, що спричиняє щоденну еволюцію нових слів. 


\title{
WORD COMPOUNDING AND WORD BLENDING AS WAYS OF FORMATION OF THE COVID-19 PANDEMIC NEOLOGISMS IN THE ENGLISH LANGUAGE
}

\author{
Zhurkova O. L. \\ Candidate of Philological Sciences, \\ Associate Professor at the Department of Foreign Philology and Translation \\ Kyiv National University of Trade and Economics \\ Kyoto str., 19, Kyiv, Ukraine \\ orcid.org/0000-0001-8113-7196 \\ o.zhurkova@knute.edu.ua
}

Key words: contamination, telescoping, word-blends, innovations, occasionalisms.
The article substantiates the expediency of studying neologisms of modern English, which represent the conceptual sphere "COVID-19 pandemic". The relevance of the study is explained by the increased attention to the influence of coronavirus on linguistic processes, including the emergence of common language and occasional innovations, which are not only of scientific interest but also of social importance. The investigation attempts to analyze ways to enrich modern English with coronavirus language units on the examples of neologisms selected from English-language sites and online publications of the British and American press. By neologisms are meant new words that are fixed in the language and created by the act of nomination, may appear to denote new concepts, or to denote in a new way already existing concepts. The study of practical material proves that the increase in the vocabulary of the English language is mainly due to changes in the meaning of existing concepts and word formation. In addition, it was found that the neologisms of the COVID-19 pandemic are dominated by those formed by compounding and blending, while the most productive components for the newly formed blend words are coronavirus/corona, COVID, quarantine, lockdown. Recently, there is a tendency to increase the lexical units-blends, and the method of word-blending is moving from the category of secondary to the category of basic. Pandemic blends (contaminants) not only name new concepts and realities in a concise form, but also perform an emotional function, as a result of which innovations often receive a negative connotative meaning due to a disapproving emotional attitude to the pandemic as such. Note that the proposed article does not claim to be exhaustive, as the COVID-19 pandemic is still ongoing, which causes the daily evolution of new words.
Постановка проблеми. Мовна ситуація, викликана пандемією COVID-19, - безпрецедентний випадок в історії людства й мови, коли за короткий проміжок часу величезна кількість нових слів, а також тих, що змінили чи доповнили своє основне значення, дають змогу зафіксувати момент мовного розвитку й мовної динаміки в найбільш концентрованій формі. Ця лінгвопсихологічна реакція на нові умови життя, особливо карантин і самоізоляцію, заслуговує на самостійне й незалежне дослідження. Актуальність розвідки зумовлюється необхідністю якнайшвидше зафіксувати, описати, зрозуміти ситуацію, що склалася, зокрема, з огляду на проблеми лексикології в широкому соціальному контексті.

Мова зазвичай відповідає на певні соціально-історичні процеси, які відбуваються в суспільстві, шляхом утворення нових слів (неологізмів) особливо через медіа простір. Однак ці словотвірні процеси не є регулярними й постійними. Здебільшого вони виникають як відповідь на конкретну інформаційну ситуацію, зникають з утратою цікавості до неї: «Якщо об'єктивно роздивлятися історію входження до узусу слів, породжених медіа ..., то за рік набирається два-три слова, що мають потенціал, який дає змогу їм стати нормативними мовними одиницями» [1, с. 52]. Іншим чином склалася ситуація 3 останніми подіями у світі під час пандемії коронавірусу. Інтернет і засоби масової інформації, що висвітлюють основні кризові моменти дійсності, стали провідними джерелами лексичних новацій. До узусу миттєво увійшли неологізми, що відобразили словотвірний потенціал медіа ресурсів, які, власне, і надають 
матеріал для численних сучасних досліджень, присвячених цій тематиці (О.І. Дзюбіна, Ю.А. Зацний, Т.В. Весна, Т.В. Телецька, Дж. Джейсі Чо, I. Маккензі, А. Рей тощо). Незважаючи на значну кількість розвідок, присвячених вивченню неологізмів пандемії COVID-19, перспектива їх подальшого дослідження залишається актуальною, оскільки еволюція таких новоутворень і досі триває.

Отже, мета статті полягає в спробі здійснення аналізу шляхів збагачення лексикону сучасної англійської мови інноваційними коронавірусними мовними одиницями, особливо зосередивши увагу на найбільш продуктивних способах словотвору - словоскладанні та словозлитті.

Зазначена мета передбачає розв'язання таких завдань:

1) дослідити неологізми й оказіоналізми англомовної лексичної системи, пов'язані з пандемією COVID-19;

2) описати найбільш продуктивні моделі, утворені шляхом словоскладання та словозлиття/ блендингу;

3) сформулювати висновки і шляхи подальших розробок у зазначеному напрямі.

Предметом дослідження визначено найпродуктивніші способи оказіонального словотвору під час пандемії COVID-19 - словоскладання та словозлиття, а об'єктом - лексичні коронавірусні неологізми, утворені зазначеним шляхом в англійській мові. Матеріалом розвідки слугували лексичні одиниці, що репрезентують концептосферу «пандемія COVID-19», отримані шляхом вибірки 3 англомовних сайтів та Інтернет-версій друкованих чи електронних 3МI.

Виклад основного матеріалу. Історично неминучим процесом $є$ поповнення лексики лінгвістичними інноваціями на позначення сучасних реалій життя - неологізмами. I.В. Арнольд стверджує, що це такі лексичні одиниці, які створені на основі словотвірних моделей чи запозичень на позначення будь-якого нового предмета або явища чи значення в уже наявних слів, що з'являються в мові на певному етапі іiі розвитку [2, с. 232].

Зарубіжний лінгвіст М. Халфан дає таку дефініцію: «Неологізмом є лексична одиниця або значення, яка виникає у визначений відрізок мовного розвитку комунікативної спільноти, отримує поширення, відповідає мовній нормі й у цей часовий проміжок розвитку сприймається більшістю носіїв мови як нова протягом визначеного часу» [3, с. 118]. Однак найбільш вичерпним ми вважаємо визначення О.О. Селіванової: «Неологізм слово чи сполука, використані мовою в певний період на позначення нового або вже наявного поняття в новому значенні й усвідомлюються як такі носіями мови» [4, с. 417].
У контексті дослідження під неологізмами ми розуміємо слова, структурно, семантично або стилістично нові, що з'явилися в мові в період пандемії COVID-19. Оскільки коронавірусна інфекція розвивалася шалено швидкими темпами та вплинула на всі сфери людського життя, деякі слова й ідеї, пов'язані 3 пандемією, самі собою представляють продукти неологізації. Деякі 3 термінів мають переосмислені значення, що створені шляхом семантичної деривації, деякі знову набули популярності в мові, отримавши позапланове оновлення. Сьогодні, за даними найвідоміших англомовних лексикографічних ресурсів, на кшталт Oxford English Dictionary, Longman English Dictionary, Collins Dictionary, MerriamWebster Dictionary, а також словників сучасного сленгу Urban Dictionary та Wordspy, лексика коронавірусної тематики увійшла до складу словників як частина лексичної системи англійської мови, при цьому один сегмент цієї лексики є складником англомовного узусу, тоді як інший усе ще має оказіональний статус.

Процес масового виникнення нових понять як стану певної мовної гіперномінативності навіть отримав термін «біфуркація»- нестабільність системи, коли виникає спектр можливостей переходу в інший стан, багатоваріантність шляхів розвитку [5]. Так, наприклад, медикалізація лексикону пояснює переміщення значної кількості слів зі сфери медицини й охорони здоров'я до узусу повсякденного та побутового спілкування. Британський мовознавець Т. Торн реконструює етапи розвитку англійської «корона-мови» (coronaspeak), прослідкувавши їі розвиток від початку пандемії. Першим етапом він називає «медикалізацію нашої повсякденної лексики (medicalisation of our everyday vocabulary)»; наступний етап характерний тим, що мовці почали вигадувати власні слова на позначення нової реальності (new reality words); третій етап автор пов'язує 3 інституціональним дискурсом, тобто мовою, яку влада використовувала для свого стратегічного плану побудови нового світу (to pursue its strategic construction of a new world) [6].

Дійсно, у процесі мовної міграції термін «соціальна дистанція» (social distance/distancing), який запозичено зі сфери соціології та політології й означає «соціологічну категорію, що характеризує ступінь прийняття або відторгнення людиною представників інших соціальних груп (етнічних, релігійних, соціально-статусних, професійних, вікових тощо)» [7] в умовах сьогодення детермінологізувався й набув нового лексичного значення: «збільшена відстань між людьми (1,5-2 метри) як протиепідеміологічний захід, офіційно рекомендована Всесвітньою організацією охорони здоров’я (BOO3) для попередження поширення 
коронавірусної інфекції» [8, с. 237]. Прикметник «віддалений» (distant) поряд із традиційними тлумаченнями, а саме: 1) такий, що «знаходиться або розташований на далекій відстані від кого-, чогонебудь; далекий»; 2) «відділений великим відрізком часу; дуже давній»; 3) «який має здійснитися в далекому майбутньому»; 4) «який не зв'язаний 3 чим-небудь прямо, безпосередньо» [9], отримує додаткове значення: «той, хто працює віддалено (у період пандемії); переведений на віддалений режим роботи у зв'язку з карантином» [8, с. 243]. Швидко проникли в мовленнєвий обіг спеціалізовані терміни «карантин» (quarantine), «ізоляиія» (isolation), змінивши своє професійно-номінативне значення: карантин - «обмеження вільного пересування здорової людини» $\rightarrow$ «максимальне обмеження зони життєдіяльності людини просторовими рамками (дім, найближчий магазин, аптека)»; ізоляція - «розташування хворого для припинення фізичного контакту зі здоровими людьми» $\rightarrow$ «перебування кого-небудь на карантині у зв'язку з підозрою в нього наявності коронавірусної інфекції COVID-19» [6].

Як уже зазначалося, метою дослідження $\epsilon$ вивчення найбільш актуальних процесів словотвору, характерних коронавірусним неологізмам. У широкому розумінні існує два способи словотвірного процесу:

1) спосіб, який застосовує такі прийоми: афіксація (affixation), словоскладання (compounding), словозлиття (blending), абревіація (abbreviation), акроніми (acronyms), усічення (clipping), запозичення (borrowing), народна етимологія (folk etymology) тощо;

2) змішаний спосіб, який застосовує декілька прийомів одночасно.

Шляхом аналізу мовного матеріалу ми дійшли висновку, що найпоширенішою моделлю для творення лексики пандемії в англійській мові є словоскладання (compounding) і словозлиття/блендинг (blending). Розглянемо їх більш детально.

$\mathrm{Te}$, що ми називаємо «словоскладанням» i «словозлиттям» (М.В. Климентьєва, Г.В. Висоцька, Т.В. Вечоринська), має значну кількість суміжних, але не завжди абсолютно синонімічних термінів, які використовуються вітчизняними та зарубіжними дослідниками: «контамінація» (Г.О. Колесник, Н.А. Лаврова, Й. Митурська-Боянова, Г. Пауль), «телескопія» (Л.Ф. Омельченко, К.С. Карова, Т.А. Чаюк, А. Зрігуе, Е. Маттіело), «блендинг» (В.І. Заботкіна, Дж. Бергстром, Дж. Кенон), а новостворені лексеми - «слова-бленди» (І.В. Андрусяк, Дж. Альджео, Дж. Кеннон, 3. Стефан) «слова-портмоне» (Т.А. Ніколаєва), «слова-валізи» (Д.С. Гриценко), «слова-злитки» (А.Ю. Мурадян), «слова-зрощення» (К.М. Вашист) тощо. Різноманіття найменувань зазначеного поняття свідчить про неоднозначність трактування цього мовного феномена, а також про недостатність його вивченості.

Словоскладання (compounding) - це спосіб утворення нових слів (compound words), який складається 3 морфологічного поєднання двох чи більше основ/коренів слів. Прикладом такого словотворення слугують англійські неологізми «coronaviva» - an oral examination or thesis defense taken online during the lockdown (усний іспит або захист під час карантину); «zoombombing»hijacking and/or interrupting videoconferencing on the Zoom platform (навмисне втручання або переривання відеоконференцзв'язку на Інтернет-платформі Zoom, коли користувач підключається до чужої зустрічі без запрошення з метою iii зриву, часто шляхом публікації неприйнятного контенту); «doomscrolling» - addiction of constant searching and reading negative news about the coronavirus (психологічна звичка, а інколи й психічний розлад, коли спостерігається залежність людини від постійного пошуку та читання негативних новин про коронавірус, але не за монітором комп'ютера, а у своєму мобільному телефоні, від англ. doom - приреченість, загибель; scroll гортати); «doomsurfing» має таке саме значення, що й «doomscrolling» із єдиною відмінністю частина «surfing» $\epsilon$ більш доречною для позначення перегляду веб-сторінок в мережі Інтернет; «sadwear» - clothes that make us feel better when we're sad, specifically born out of the existential ennui of lockdown (одяг, який змушує нас почуватися краще під час самоізоляції чи локдауну).

Ще одним методом формування неологізмів COVID-19 є словозлиття/блендинг (blending) - це спосіб утворення нової лексеми шляхом злиття двох чи більше повнозначних, ситнагматично не пов'язаних слів, причому нерідко це відбувається несвідомо. Тобто основна відмінність цього способу від вищезгаданого в тому, що останній поєднує не цілі лексеми, а їх частини в новому слові. Значення такої лексичної одиниці є сумою значень лексем, що його мотивує. Процес формування словозлиття $є$ перетином усвідомлюваних і несвідомих процесів, основна функція якого - зацікавити сприймача інформації, привернути його увагу.

Ера пандемії COVID-19 надала нову хвилю популярності словозлиттю в засобах масової інформації, соціальних групах і мережі Інтернет. Значна частина «коронеологізмів» - слів, які самі по собі є поєднанням слів «коронавірус» + «неологізм» - створені журналістами британської преси. Бленд «coronaverse» (coronavirus + universe) уперше використаний авторитетним виданням «the Guardian», «lockstalgia» (lockdown + nostalgia) - «the Times», a «covidpreneurs» (COVID + entrepreneurs) $-\ll$ the Irish Times». 
Варто підкреслити, що словозлиття/блендинг уважався доволі екзотичним способом словотвору, донедавна слова-бленди рахувалися одиницями. Однак останнім часом кількість слів, утворених шляхом контамінації, значно зросла, цей спосіб словотвору перейшов 3 розряду другорядних у категорію основних [10, с. 290]. Цей факт, на нашу думку, пов'язаний з роллю, що зростає, мас-медіа, реклами, мережі Інтернет, міжкультурних контактів, а також популяризацією й затребуваністю англійської мови та культури, де спосіб контамінації знаходить своє найширше розповсюдження. Ретельний аналіз цього явища дає змогу переконатися, що його когнітивне й комунікативне призначення значно ширше та важливіше, ніж ігрова чи експресивна функції.

Неологізми пандемії COVID-19, утворені шляхом словозлиття, можна умовно поділити на певні тематичні групи, де одним із компонентів бленду $\epsilon$ найбільш уживані лексеми, як-от:

1) «coronavirus»/《corona»: coronacation (corona + vacation) - cessation of study or work due to the pandemic, viewed as a holiday (канікули у зв'язку з пандемією коронавірусу); coronartunity (corona + opportunity) - an opportunity created by the coronavirus pandemic to spend time on a house project, catch up on sleep, or do anything else you would normally not get to do (можливість зайнятися хатніми справами, відіспатися чи зробити щось під час самоізоляції, на що зазвичай не вистачає часу); coronapocalypse (corona + apocalypse) та coronageddon (corona + armageddon) - the nearcertain, end-of-times condition created either by the actual COVID-19 virus or the massive social, financial and political devastation generated on the back of global hysteria (кінець світу або масове соціальне, фінансове та політичне спустошення на тлі глобальної істерії, що створена пандемією COVID-19);

2) «covid»: covidiot (COVID + idiot) - someone who ignores the warnings regarding public health or safety (той, хто ігнорує попередження й поради та йде проти рекомендацій суспільної охорони здоров'я під час пандеміï); covidiction (COVID + addiction) - the addiction of searching the web and e-dashboards, with an urge to see the increase in number of affected and mortality count due to COVID-19 (залежність від пошуку в мережі Інтернет інформації про зріст постраждалих і рівень смертності від COVID-19); covidivorse (COVID + divorse) - the breakdown of relations due to pandemic (розлучення через перебування в замкненому просторі під час пандемії);

3) «quarantine»: quaranteens (quarantine + teens) - teenagers who have experienced the coronavirus (підлітки в період коронавірусу); quarantini (quarantine + martini) - a martini mixed and consumed in conditions of confinement («карантині» - алкогольний коктейль 3 мартіні, який уживають під час самоізоляції); quaranrtroll (quarantine + trolling) - an individual sending malicious online messages in conditions of and/or referring to quarantine (особа, що надсилає вірусні онлайн-повідомлення про карантин або під час карантину);

4) «lockdown»: loxit (lockdown + exit) - the process of exiting from lockdown impositions (закінчення коронавірусної самоізоляції); locktail (lockdown + cocktail) - a lockdown cocktail, often made with Warner's Gin (коктейль із використанням джину під час локдауну чи самоізоляції); lockstalgia (lockdown + nostalgia) - the notion that we may look back fondly upon the period of confinement (відчуття ностальгії, туги за самоізоляцією).

Висновки й перспективи подальших розробок. Підсумовуючи вищезазначене, варто підкреслити, що на сучасному етапі розвитку світової цивілізації найбільш важливою та обговорюваною подією в медіа просторі стала глобальна пандемія COVID-19. Саме це явище, а також світовий локдаун, викликаний ним, створили передумови для появи загальномовних неологізмів та оказіональних індивідуально-авторських новоутворень. Поряд зі значною кількістю словотвірних процесів на позначення нової мови пандемії найбільш продуктивними на цей час моделями в англійській мові є словоскладання та словозлиття/блендинг. Аналіз мовного матеріалу дав змогу визначити найбільш ефективні компоненти для створення слів-блендів нової реальності, серед яких «coronavirus»//(corona», «COVID», «quarantine», «lockdown». Процес лінгвістичних інновацій привернув увагу мовознавців і лексикографів, а найбільш авторитетні словники англійської мови опублікували та створили розділи й сайти, присвячені мові COVID-19. Цей факт підтверджує, що неологізми $є$ відображенням мовних змін i розвитку.

Перспективами подальших досліджень у визначеному напрямі можна вважати поглиблене вивчення лексико-семантичних, функціонально-стилістичних і лінгвокультурологічних особливостей коронавірусного вокабуляру в різних мовах у тому числі в зіставному аспекті.

\section{ЛІТЕРАТУРА}

1. Русский язык коронавирусной эпохи : коллективная монография / Т.Н. Бурцева, Х. Вальтер, И.Т. Вепрева, Р.И. Воронцов, Е.Н. Геккина. Санкт-Петербург : Институт лингвистических исследований РАН, $2021.610 \mathrm{c}$. 
2. Арнольд И.В. Лексикология современного английского языка : учебное пособие. Москва : ФЛИНТА : Наука, 2012. 376 с.

3. Khalfan M., Batool H., Shehzad W. COVID-19 Neologisms and their Social Use : An Analysis from the Perspective of Linguistic Relativism. Linguistics and Literature Review. 2020. № 2. P. $117-129$.

4. Селіванова О.О. Сучасна лінгвістика: термінологічна енциклопедія. Полтава : Довкілля К, 2006. $718 \mathrm{c}$.

5. Щигло Л.В. Мова як об'єкт синергетичного вивчення: електронна версія. URL: https:// www.sworld.com.ua/simpoz8/95.pdf.

6. Thorne T. Spotlight on COVID: Pandemic language and the role of linguistics. King's College London, 2020. URL: https://kcl.ac.uk/ news/spotlight-on-covid-pandemic-languageand-the-role-oflinguists-1.

7. Паніна Н.В. Дистанція соціальна. Енциклопедія сучасної України: електронна версія : веб-сайт. Київ : Інститут енциклопедичних досліджень НАН України, 2007. URL: https://esu.com.ua/ search articles.php?id $=24379 \mathrm{~m}$.

8. Вальтер Х., Громенко Е.С., Кожевников А.Ю., Козловская Н.В., Козулина Н.А. Словарь русского языка коронавирусной эпохи. Санкт-Петербург : Институт лингвистических исследований РАН, 2021. 550 с.

9. Академічний тлумачний словник української мови: електронна версія. 2018. URL: http:/ sum.in.ua/s/viddalenyj.

10. Шейфель Н.А. Понятие блендинга и его отличие от других смежных способов словообразования в лингвистике. Современные проблемы языкознания, литературы, межкультурной коммуникаиии и лингводидактики : материалы II Международной научной конференции. Белгород, 20-21 апреля 2016. С. 290-294.

\section{REFERENCES}

1. Burtseva, T., Walter, Kh., Vepreva, I., Vorontsov, R., \& Gekkina, E. (2021) The Russian language of the coronavirus era: a collective monograph. [Russkiy yazyk koronavirusnoy yepokhi: kollektivnaya monografiya]. St. Petersburg : Institute for Linguistic Research RAS, pp. 610 [in Russian].
2. Arnold, I. (2006) Lexicology of modern English: textbook. [Leksikologiya sovremennogo angliyskogo yazyka: ucheb. posobiye]. Moscow : FLINT: Nauka, pp. 376 [in Russian].

3. Khalfan, M., Batool, H., \& Shehzad, W. (2020) COVID-19 Neologisms and their Social Use: An Analysis from the Perspective of Linguistic Relativism. Linguistics and Literature Review. (2), 117-129 pp. [in English].

4. Selivanova, O. (2006) Modern linguistics: terminological encyclopedia. [Suchasna linhvistyka: terminolohichna entsyklopediya]. Poltava : Dovkillya - K, pp. 718 [in Ukrainian]

5. Shchiglo, L. (2017) Language as an object of synergetic study. [Mova yak ob'yekt sinerhetychnoho vyvchennya]. Electronic version [website]. URL: https://www.sworld.com.ua/ simpoz8/95.pdf [in Ukrainian].

6. Thorne, T. (2020) Spotlight on COVID: Pandemic language and the role of linguistics. URL: https:// $\mathrm{kcl}$.ac.uk/news/spotlight-on-covid-pandemiclanguage-and-the-role-oflinguists-1 [in English].

7. Panina, N. (2007) The distance is social. Encyclopedia of Modern Ukraine. [Dystantsiya sotsial'na. Entsyklopediya Suchasnoyi Ukrayiny]. Electronic version [website]. URL: https:// esu.com.ua/search_articles.php?id=24379m [in Ukrainian].

8. Walter, Kh., Gromenko, E., Kozhevnikov, A., Kozlovskaya, N., \& Kozulina, N. (2021) Dictionary of the Russian language of the coronavirus era. [Slovar' russkogo yazyka koronavirusnoy yepokhi]. St. Petersburg: Institute for Linguistic Research RAS, pp. 550 [in Russian].

9. Academic explanatory dictionary of the Ukrainian language. (2018) [Akademichnyy tlumachnyy slovnyk ukrayins'koyi movy]. Electronic version [website] URL: http://sum.in.ua/s/viddalenyj [in Ukrainian].

10. Sheifel, N. (2016) The concept of blending and its difference from other related ways of word formation in linguistics [Ponyatiye blendinga $\mathrm{i}$ yego otlichiye ot drugikh smezhnykh sposobov slovoobrazovaniya v lingvistike]. Modern problems of linguistics, literature, intercultural communication and linguadidactics: materials of the 2nd International Scientific Conference. Belgorod, April 20-21, 290-294 pp. [in Russian]. 